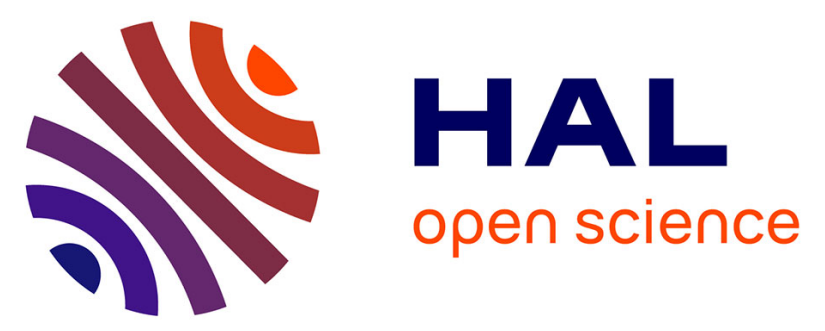

\title{
PROFESSIONALIZATION IN SAFETY: A STUDY OF THE FUNDAMENTAL KNOWLEDGE OF FUTURE SAFETY PROFESSIONALS
}

Wim van Wassenhove, Christian Foussard

\section{- To cite this version:}

Wim van Wassenhove, Christian Foussard. PROFESSIONALIZATION IN SAFETY: A STUDY OF THE FUNDAMENTAL KNOWLEDGE OF FUTURE SAFETY PROFESSIONALS. 30th European Safety and Reliability Conference and the 15th Probabilistic Safety Assessmentand Management Conference, Nov 2020, Venice, Italy. 10.3850/978-981-14-8593-0 . hal-03236336

HAL Id: hal-03236336

https://hal-mines-paristech.archives-ouvertes.fr/hal-03236336

Submitted on 2 Jun 2021

HAL is a multi-disciplinary open access archive for the deposit and dissemination of scientific research documents, whether they are published or not. The documents may come from teaching and research institutions in France or abroad, or from public or private research centers.
L'archive ouverte pluridisciplinaire HAL, est destinée au dépôt et à la diffusion de documents scientifiques de niveau recherche, publiés ou non, émanant des établissements d'enseignement et de recherche français ou étrangers, des laboratoires publics ou privés. 


\title{
PROFESSIONALIZATION IN SAFETY: A STUDY OF THE FUNDAMENTAL KNOWLEDGE OF FUTURE SAFETY PROFESSIONALS
}

\author{
Wim VAN WASSENHOVE \\ CRC MINES ParisTech /PSL Research University, France. \\ E-mail:wim.van_wassenhove@mines-paristech.fr \\ Christian FOUSSARD \\ Consultant Risk Management \& Process Safety, Senior Lecturer, Dubai United Arab Emirates. \\ E-mail: christian.foussard@mines-paris.org
}

This contribution to the ESREL conference will present an expérimentation about testing fundamental knowledge of future safety professionals. The post master Management of Industrial Risks has graduated more than 250 students since 2004. The program addresses Occupational Health and Safety and Industrial Safety topics. Most of the students find a job related to one of those two domains.

The program recruits among a large panel of Master Programs, going from Safety, Health, Quality, and Environment. Students then follow a 500 hours program and they do a 1000 hours internship. The question we arise is "What is the fundamental knowledge a safety professional needs to master?" And how can we assure that a student graduated from the program masters this knowledge?

This article will present how fundamental knowledge for safety professionals is identified and how this knowledge is assessed. A fundamental knowledge assessment was done on one cohort of students and their feedback on this test is collected. This kind of test develops their meta-knowledge in the safety domain. A critical reflection about learning in the safety domain and quality analysis of safety education programs is made and perspectives about future curricula are proposed.

Keywords: professionalization in safety, safety fundamental knowledge, safety education programs.

\section{Introduction}

The post master Management of Industrial Risks has graduated more than 250 students since 2004. The program addresses Occupational Health and Safety and Industrial Safety topics. Most of the students find a job related to one of those two domains. The program is recruiting candidates detaining a diploma among a large panel of Master Programs, going from Risk Management, Safety, Health, Quality, Environment. The question we arise is "What is the fundamental knowledge a safety professional needs to master?" And how can we assure that a student graduated from the program masters this knowledge? This contribution to the ESREL conference will present an expérimentation about testing fundamental knowledge for the future safety professional.

\section{Professionalization of Safety}

Several authors described the professionalization of safety. One of the first publications on the safety professional was done in the '60s (Harper, Rockwell, and Weaver 1962). Andrew Hale has took the lead for the topic since the "70s (Atherley and Hale, 1975) and several other authors have worked on the topic. An important work has been done in identifying the missions of the safety professional (Hale et al. 2005) (Chang, Chen and $\mathrm{Wu}, 2012$ ) (Arezes and Swuste 2012) (Wu 2011) (Meyer, 2015). Limburg (1995) worked on identifying the competences for the safety professional. Marshall and Mackey (1995), Swuste and Arnoldy (2003) and Pryor (2016) did some research on safety professional education. Wybo and Van Wassenhove (2016) present in their paper the creation of a post master safety education program. We will present very shortly this program in the next section. 


\section{Post Master Program Industrial risk Management}

\subsection{Presentation of the program}

MINES ParisTech university was created in the late 18th Century - by Louis XVI - with the aim of training high-level professionals to support the rapid development of industry and mines. Among the missions of those "engineers" (the word didn't exist at that time) was the objective of minimizing risks associated with those new technologies. In 2002, the decision was taken to build a full time post-master program for training HSE professionals for the industry. The design of the curriculum was achieved from an analysis of academic literature and current practices, in close cooperation with companies' representatives, in order to fit the contents of the training and the pedagogical methods to the needs of the industrial sector. We aim at forming preventer-managers. The program was finally launched in 2004 by the Center for Research on Risks and Crises (CRC) of MINES ParisTech. The curriculum contains six main tracks:

- Safety regulations: understanding the organization of the HSE regulations (European, national), knowing the most important tools used to comply with regulations

- Hazard and risk assessment: knowing the most important methods and tools used for hazard and risk analysis (like HAZOP, PRA, bow tie diagrams, ...);

- HSE management systems: understanding the conception and implementation of HSE management systems, knowing the most important certifications (OHSAS 18000, $\ldots)$;

- Human and organizational aspects: knowing and understanding the issues going from human error to psychosocial risks;

- Management and leadership aspects: knowing how to communicate and how to manage people;

- Emergency and crisis management: knowing and understanding methods and tools for emergency and crisis management (emergency plans, business continuity plans, crisis communication,...).

Lectures, exercises and practical work are provided and supervised by a faculty group composed of an equal number of academics and professionals. Case studies and team project work are for example occupational risk identification for a company (chemical laboratory, cosmetics production site, mechanics workshop,...), major risk modeling for industrial sites (gas storage site), safety management audits (contractor issues), rehabilitation projects of polluted sites, comparing psychosocial risk evaluation methods, human error analysis for accidents,... (Foussard \& Van Wassenhove, 2019). The program includes 500 hours of teaching time. Most of the students have a one year apprenticeship with an industrial partner, working on a practical problem for this industrial partner.

\subsection{Diversity in IRM candidates background}

Nowadays, every industrial company is part of a global network, uniting several entities into networks all over the world: production and logistics sites, administrative, research and development sites, suppliers and customers. Managers and staff must be able to work in teams composed of a variety of nationalities, cultures and backgrounds, which needs to develop interpersonal skills and a high degree of open-mindedness.

In order to address this important aspect, we build each cohort of students for the post master program as a mixed team, gathering students from different backgrounds (engineering sciences, social sciences, business and management sciences) and from different origins and cultures. This diversity is obtained by a general communication of the program. As a result, candidates of various backgrounds apply to the program, the selection jury looks into each candidature and pays special attention to the pertinence of the candidate's professional project. By making them work together on different projects, participating in different small teams for each project, playing the role of team leader and team member alternatively, they have many opportunities to understand and value their differences, make an efficient use of each individual skill and verify that such a diversity is valuable to produce richer results.

This diversity is appreciated by the students and is indicated as a positive point of the program by the students in the final program evaluation. Whilst there are many pros, some cons of that diversity can be observed; students with a professional experience can tend to be "bossy" towards students who follow the program directly after their master degree. Students with a social science background can have difficulties to follow the technical courses of the program and some language/cultural problems can rise. But maybe the main difficulty is the difference in the knowledge and competency level for HSE and risk domains of those future safety professionals. 
This diversity of the academic background of the IRM students tends however to become lesser as the industrial partners prefer students with already a background in Health, Safety or Environment. The academic background of the 2019-2020 cohort is presented in table 1.

Table 1: Academic background of the 36 IRM students, cohort 2019-2020.

\begin{tabular}{|l|c|}
\hline \multicolumn{1}{|c|}{ Academic background } & $\begin{array}{c}\text { Number of } \\
\text { students }\end{array}$ \\
\hline $\begin{array}{l}\text { Master in Health, Safety and } \\
\text { Environment }\end{array}$ & 1 \\
\hline Master in Health & 4 \\
\hline Master in Environment & 6 \\
\hline Master Risk Management/HSE & 10 \\
\hline Master Quality, Safety, Environment & 2 \\
\hline $\begin{array}{l}\text { Master in mechanics, fire safety } \\
\text { engineering }\end{array}$ & 1 \\
\hline HSE engineer & 1 \\
\hline Chemical engineer & 1 \\
\hline Process engineer & 1 \\
\hline Mining engineer & 1 \\
\hline $\begin{array}{l}\text { Bachelor in Health, Safety and } \\
\text { Environment }\end{array}$ & 1 \\
\hline Master in law (insurance) & 1 \\
\hline Master in geology & 1 \\
\hline professional fire fighter & 1 \\
\hline Engineer in telecommunications & 1 \\
\hline & 1 \\
\hline
\end{tabular}

\section{Fundamental Safety Knowledge}

\subsection{Learning objectives for safety education programs}

Research into safety education has recently gained in interest but quality in safety education is a topic not commonly addressed in scientific literature. The paper of Van Wassenhove et al (2019) describes the proposition of nine European safety education program directors for a model of a quality (post) graduate safety education program. A major point in this quality evaluation is choosing learning objectives. What kind of knowledge and competences a graduate student must master at the end of a safety education program? And logically, what kind of knowledge and competences a student must master when entering this education program? Post graduate safety education is mostly a one or two year program. Students entering the program come from various backgrounds, chemical engineers, process engineers, master in quality and environment, master in public health, master in occupational health and safety, master in ergonomics and even master in law (see table 1). All those students are lacking knowledge and competences but at different levels and domains. When they complete the safety program, most of the lacking knowledge and competences are acquired by the students, but not all and not at the same level and in the same domains. Several solutions exist to tackle this problem. We will present here a solution tested for the post master program "industrial risk management".

\subsection{Professionalization and profession}

In literature, different approaches to characterize a profession exist (Wilenski, 1964; Abbott, 1988; Demazière and Gadea, 2009; Champy, 2012). Ferguson and Ramsay (2010) presents in their paper three common admitted characteristics of a profession:

1. The existence of a « Body of Knowledge » that is dispensed by recognized education programs.

2. A professional organization that can pronounce on the level of qualification of a professional.

\section{A code of professional ethics.}

In our case, the body of knowledge is what we want to explore. Several authors already worked on fundamental knowledge and competences for the safety professional. An important job has been done by the Safety Institute of Australia (SIA) (Pryor, 2019; Pryor et al, 2019) by developing the core body of knowledge for the generalist OHS professional. We analyzed several sources of fundamental knowledge for the safety professional. From those sources, we proposed a classification that suits for the IRM program and that embraces the knowledge a student graduated from the IRM program has to know. The next section presents our methodology.

\section{Methodology}

\subsection{Fundamental knowledge identification methodology}

We started with the INSHPO Capability Framework (International Network of Safety and Health Professional Organizations), it represents 
a work with the largest scope of contributors. It also integrates work from EUSafe and the BoK (Book of Knowledge). The structure and organization of Knowledge proposed by INSHPO was used as a standard to compare other references: INRS (Institut National de Recherche et de Sécurité pour la prévention des accidents du travail et des maladies professionnelles, France), HSE (Health and Safety Executive, NEBOSH certification, National Examination Board in Occupational Safety and Health, United Kingdom), ASSE (American Society of Safety Engineers, now became ASSP American Society of Safety Professionals, BCSP, Board of Certified Safety Professionals, United States of America), SIA (Safety Institute of Australia, Bok, Book of Knowledge, Australia). One supplementary column was added to propose items or themes that weren't present in any reference (because particular to French legal context for example). A first categorization was thus presented:

\section{Science}

2. Risk

3. Regulations and socio-cultural context

4. Safety management

5. Management and control

\section{Emergency}

Those six categories were finally further reduced to only four. The logic behind this is the following: Science is the fundamental knowledge to understand phenomena. This knowledge permit to understand hazards and "conceive risk". Risk is treated in a regulatory frame and finally, risk is managed. The fundamental knowledge items were thus finally structured in four categories:

1. Science: Knowledge of engineering sciences (mathematics, physics, chemistry,...) and social sciences (psychology, ergonomics,...)

2. Hazard and Risk: Contains all hazards and risks in occupational health and safety, process safety, security and cybersecurity.

3. Regulations: French, European and international regulations, Certifications (ISO)

4. Management: Management systems, safety culture models, emergency and crisis management.

This represents about 15 pages of tables of "safety professional knowledge items" categorized in the four categories. Next step was to index the knowledge items with five different levels:

1. Fundamental science knowledge (high school or bachelor level) - supposed acquired by IRM candidates

2. Fundamental safety knowledge prerequired for comprehension of IRM program supposed acquired by IRM candidates

3. Fundamental safety knowledge that will be acquired while doing the IRM program

4. Safety knowledge acquired while doing the IRM program

5. Safety knowledge expert level, not treated in IRM program

The knowledge items were indexed according the five levels. This was done by four persons in a five hours reunion: a safety professional expert (Occupational Health and Safety and Process Safety), the director of the IRM program, a lecturer of the IRM program and a junior safety professional who is alumni of the IRM program. 36 knowledge items were identified level two: fundamental safety knowledge prerequired for comprehension of IRM program. This is the basic level of knowledge a Master student in safety has to master.

\subsection{Elaboration of questionnaires and the subjectivity of experts}

In order to test the level two fundamental knowledge that was identified, examinations have to be developed. It was decided to do in the first place an open questions examination. From the 36 fundamental themes, 56 questions were created. The NEBOSH examinations for the general certificate and for process safety management were used to inspire the questions. Some examples are:

“ What does P.I.D. signifies?" (? Process Instrumentation Diagram)

"What is the difference between a P.I.D. and a P.F.D.? (P.FD. = Process Flow Diagram)

“What signifies ALARP?" (? As Low As Reasonably Possible)

"What are the two dimensions of the risk matrix?" (? Occurrence and Gravity)

For a second test, 37 multiple choice questions were created. 
Each question was attached to one of the 36 knowledge items and for each of the 36 items, a documentation was supplied so that the students could afterwards update their knowledge in autonomy.

A senior safety professional (expert process safety and occupational health and safety) coconstructed the questions. The questions were submitted to another senior safety professional, also expert in the two domains. It appeared that the first series of questions were not all of them easy to interpret. Senior expert safety professionals can have a particular vision of their domain (and what is important and what not) and that vision is not general to all senior experts, they tend to put different accents to what is really important. This is an interesting topic to investigate in the future.

\section{Results}

Two examinations were organized. The students of the 2019-2020 cohort took the examinations. The students were told that it was an autoevaluation of their fundamental HSE knowledge level.

A first examination was done in the beginning of the program, 35 students took it (one absence). Is was an open question examination of 56 questions. After the test, a feedback was organized and students could report their impressions. Later on, we organized a group correction and each student made the correction of his own examination, we did not collect the copies afterwards, each student kept his copy. What imported to us was the global score of the group for each question, not individual scores of students. The students received documentation on the fundamental knowledge domains so they could in autonomy reinforce their weaknesses.

The second examination was a multiple choice question list of 37 questions that tested the same corpus of knowledge. This was organized three months after the first examination and the purpose was to stimulate the students to work on the weaknesses in their fundamental knowledge. The students didn't knew beforehand when and if this second examination was held. 33 students took the second examination (three absent due to illness).

\subsection{Examination 1}

The results were rather very poor (figure 1, percentages with right answer) but this was not as much as a surprise. The content of the examination was in a great amount focused on industrial risk (or process safety). Most of the students had an occupational health and safety background, so several subjects were new to them. It appeared also that answering to a question "out of the context" is very difficult for students. Maybe the questions have to be more "introduced" or "contextualized". Some questions (and answers associated) were the vision of one professional expert and represent his vision only (as discussed above). Some questions were to technical and are normally not know by heart by a safety professional (it would be interesting to do the same examination with safety professionals).

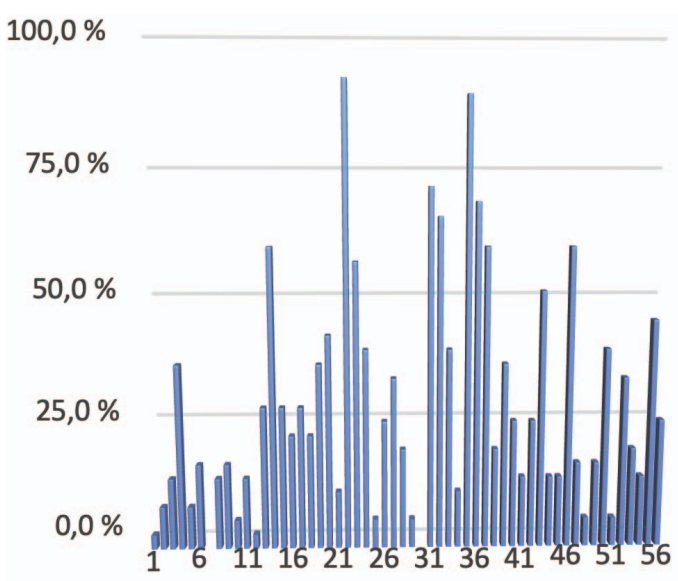

Figure 1 : results first examination (56 questions)

Three days after the examination, a written feedback (Composed by four questions and the opportunity to leave a comment) was organized. Although the bad results, the feedback of the students was very positive.

\section{Questions were too difficult?}

Most of the students (23/35) found the examination too difficult for them but they recognized the pertinence of the examination. It was for them the opportunity to check their level of knowledge compared to the standard of a safety professional. 12 of them didn't found it too difficult.

\section{Examination was too long}

Most of the students (28/35) found the examination and the time given to realize it (two hours) not too long. The general format of the examination was considered very adequate by the students.

\section{Questions were representative of my past education}

19 students agreed with the fact that the questions were in line with the knowledge acquired in their past education curriculum. 16 students mentioned important lacks of 
knowledge due to their past education, mostly concerning process safety.

\section{The knowledge tested corresponds to what I will use in the future?}

No single student mentioned the fact that the knowledge tested doesn't correspond to what he/ she will mobilize in his future career. This sounds logical, we presented the test and its' domains as the fundamental knowledge for safety professionals. It was in that regard somehow impossible for them to counter argue this.

\subsection{Examination 2}

The results for the second examination were far better, but still not excellent (Figure 2, percentages with right answer). Some questions of the multiple choice were a bit tricky (or confusing). The group correction (each student made the correction of his own examination, we did not collect the copies afterwards, each student kept his copy) revealed some questions that have to be better addressed.

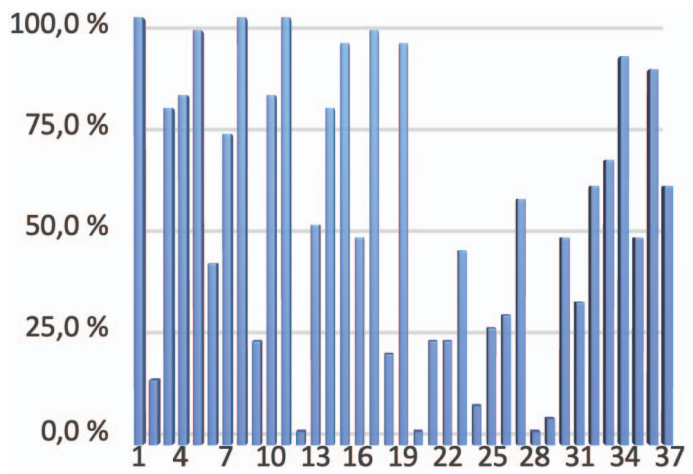

Figure 2 : results second examination (37 questions)

\section{Discussion}

Educational background of students is different. This is a strength for the education program but a difficulty faced by a program director. $\mathrm{He} / \mathrm{she}$ has to determine learning objectives based on fundamental knowledge requirements to dress the learning path to achieve the objectives. A post master 500 hours program can't deal with all the knowledge items concerned by a safety professional. Choices have to be made. It is useful for the students to dress them the result of those choices and the general overview of all the safety professional knowledge, what is fundamental, what will be taught at the program and what will be necessary for them to learn in autonomy. But what is important is to give to students the opportunity to evaluate themselves.
Next point to discuss is the pertinence of such kind of knowledge testing. It would be interesting to test safety professionals' knowledge and compare the obtained results with the students' results. Knowing by heart specific detailed technical knowledge isn't maybe an indicator for a good safety professional. A good safety professional perhaps knows where to find rapidly the right knowledge for his needs. For instance, it is important to know the general regulations about noise on the work floor and where to find this regulation rather than to know exactly each noise limit. Questions addressed have to aim the right amount of "detail" of the fundamental knowledge. Not too general (because too simple) and not too much detail (too difficult).

We can address some general remarks for safety education programs, they maybe focus too much on technical aspects of the safety professionals' knowledge body. Strategic, holistic management view may be lacking, also reflexivity on the role of the safety professional in an organization (Provan et al, 2017). Students are regularly asking for technical knowledge, for "toolboxes". In their perspective, it is needed to be confident but perhaps this isn't the way to make them confident. Nowadays, safety professionals in organizations need to master financial aspects and need to have the competency of critical analysis. Transversal human factor competences like negotiation, argumentation, human resource management are expected from a modern safety professional. For technical knowledge he/she can make appeal to his professional network where he/she can also share his own knowledge. Knowing what we know and knowing where to find lacking knowledge is an important competency in a fast-changing world.

\section{Conclusion}

Research is actually done on the evolution of a global, professional capability framework covering the role, contribution and status of Occupational Health and Safety (OHS) professionals (Hale et al, 2020). The issue of fundamental knowledge for the safety profession is important for program directors but also for students as the domain can be beyond OHS. Safety professionals treat also process safety or industrial safety and they can be confronted with security or cyber security issues. A clear vision from the student on his/her knowledge and his/ her competences and on the global safety profession domain is important. Presenting a global body of knowledge to the students and testing them on fundamental knowledge is one way to improve their vision. 


\section{References}

Abbott A. 1988. The system of Professions: An essay on the division of expert labor. University of Chicago Press.

Arezes, P. M. and Swuste, P. 2012. Occupational Health and Safety Post-Graduation Courses in Europe: A General Overview. Safety Science 50 (3): 433-42.

Atherley, G.R.C. and Hale A.R. 1975. Prerequisitiesfor a profession in occupational safety and hygiene. Ann. Occup. Hyg. 18, 321-258.

Champy F. 2012. La sociology des professions. Editions PUF.

Chang, Shu-Hsuan, Der-Fa Chen, and Tsung-Chih Wu. 2012. Developing a Competency Model for Safety Professionals: Correlations between Competency and Safety Functions. Journal of Safety Research 43 (5-6): 339-50.

Demazière D. and Gadea C. 2009. Sociologie des groups professionnels: acquis récents et nouveau défis. Ed Découverte.

Ferguson L.H. and Ramsay J.D., 2010. Development of a profession - The role of education and certification in occupational safety becoming a profession. Professional safety, October 2010, ASSE.

Foussard, C., \& Van Wassenhove, W. (2019). Professionalization in Safety: Creating Effective Learning Environments. ESREL conference 2019.

Hale, A. R., G. Bianchi, G. Dudka, W. Hameister, R. Jones, P. Perttula, and I. Ytrehus. 2005. Surveying the Role of Safety Professionals: Objectives, Methods and Early Results. Safety Science Monitor 9 (1).

Hale, A.R., Hudson D. and Pryor P. 2020.The evolution of a global, professional capability framework covering the role, contribution and status of Occupational Health and Safety (OHS) professionals: Editorial, introduction and discussion. Safety Science 122

Harper G.W., Rockwell T.H. and Weaver D.A. (1962) The Safety Engineer. Part I: What Do We Expect of the Safety Engineer? A.S.S.E. Journal, VII-2

Limburg H.J. (1995). Qualifying the consultative skills of the occupational health service staff, Safety Science $20,247-252$

Marshall, E. and Mackey, M. 1995. Professional Education in Occupational Health and Safety in Australia. Safety Science 20 (2): 207-211.
Meyer, T. 2015. Towards the Implementation of a Safety Education Program in a Teaching and Research Institution. Education for Chemical Engineers, (June).

Provan, D. J., Dekker, S.W.A. and Rae A.J.. 2017. Bureaucracy, Influence and Beliefs: A Literature Review of the Factors Shaping the Role of a Safety Professional. Safety Science 98 (October):98-112.

Pryor P. Hale, A.R., and Hudson D. 2019. Development of a global framework for OHS professional practice. Safety Science 117, 404-416.

Pryor, P. 2016. Accredited OHS Professional Education: A Step Change for OHS Capability. Safety Science 81 (January): 5-12.

Pryor, P. 2019. Developping the core body of knowledge for the generalist OHS professional. Safety Science 115, 19-27

Swuste, P. and Arnoldy, F. 2003. The Safety Adviser/manager as Agent of Organisational Change: A New Challenge to Expert Training. Safety Science 41 (1): 15-27.

Van Wassenhove, W., Swuste, P., Forteza F.J., Carretero-Gomez, J.M., Arezes, P., Kivistö-Rahnasto, J., Motet, G., Reyniers, K., Galera, A. and Wenham D. 2019. Quality of Graduate Health and Safety Education Programs: A General Model Illustrated with Examples of Nine (post)Graduate Courses in Europe. DOI: 10.20944/preprints201911.0276.v1

Wilensky H. L. 1964. The professionalization of everyone? American Journal of Sociology. Vol 70, N 2 September 1964.

Wu, T-C. 2011. The Roles and Functions of Safety Professionals in Taiwan: Comparing the Perceptions of Safety Professionals and Safety Educators. Journal of Safety Research 42 (5): 399407.

Wybo, J-L. and Van Wassenhove, W. 2016. Preparing Graduate Students to Be HSE Professionals. Safety Science 81 (January): 25-34. 